\title{
Retraction Note: Fuzzy fractional Ostrowski inequality with Caputo differentiability
}

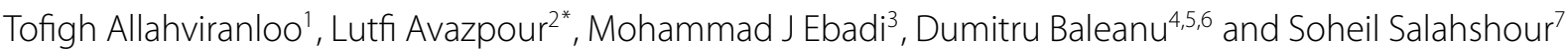

\section{"Correspondence:}

avazpour.@gmail.com

${ }^{2}$ Department of Mathematics,

Yasooj Branch, Islamic Azad

University, Yasooj, Iran

Full list of author information is

available at the end of the article
The manuscript [1] has been retracted by the editor as a request of one of the authors (Dumitru Baleanu). He realized that the version submitted by the corresponding author was not in the final form. The authors were advised to resubmit their paper after making necessary corrections.

\footnotetext{
Author details

'Department of Mathematics, Science and Research Branch, Islamic Azad University, Tehran, Iran. ${ }^{2}$ Department of Mathematics, Yasooj Branch, Islamic Azad University, Yasooj, Iran. ${ }^{3}$ Faculty of Marine Science, Chabahar Maritime University, Chabahar, Iran. ${ }^{4}$ Department of Mathematics and Computer Sciences, Cankaya University, Ankara, 06530, Turkey. ${ }^{5}$ Department of Chemical and Materials Engineering, Faculty of Engineering, King Abdulaziz University, Jeddah, Saudi Arabia. ${ }^{6}$ Institute of Space Sciences, Magurele, Bucharest, Romania. ${ }^{7}$ Young Researchers and Elite Club, Mobarakeh Branch, Islamic Azad University, Mobarakeh, Iran.

Received: 13 August 2013 Accepted: 14 August 2013 Published: 30 August 2013

References

1. Allahviranloo, T, Avazpour, L, Ebadi, MJ, Baleanu, D, Salahshour, S: Fuzzy fractional Ostrowski inequality with Caputo differentiability. J. Inequal. Appl. 2013, 50 (2013)
}

doi:10.1186/1029-242X-2013-417

Cite this article as: Allahviranloo et al.: Retraction: Fuzzy fractional Ostrowski inequality with Caputo differentiability. Journal of Inequalities and Applications 2013 2013:417.

\section{Springer}

(c) 2013 Allahviranloo et al.; licensee Springer. This is an Open Access article distributed under the terms of the Creative Commons Attribution License (http://creativecommons.org/licenses/by/2.0), which permits unrestricted use, distribution, and reproduction in any medium, provided the original work is properly cited.
Submit your manuscript to a SpringerOpen ${ }^{\circ}$ journal and benefit from:

- Convenient online submission

- Rigorous peer review

- Immediate publication on acceptance

- Open access: articles freely available online

- High visibility within the field

- Retaining the copyright to your article

Submit your next manuscript at $>$ springeropen.com 